\title{
Parasites and People
}




\section{Parasites and People}

\section{D.W.T. CROMPTON}

Department of Parasitology

The Molteno Institute

University of Cambridge

Cover design and illustrations

Paula Disanto Bensadoun

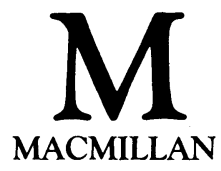


(C) D.W.T. Crompton 1984

All rights reserved. No part of this publication may be reproduced or transmitted, in any form or by any means, without permission.

First published 1984

Published by

Higher and Further Education Division MACMILLAN PUBLISHERS LTD

Houndmills, Basingstoke, Hampshire RG21 2XS and London

Associated companies in Auckland, Delhi, Dublin, Gaborone, Hamburg, Harare, Hong Kong, Johannesburg, Kuala Lumpur, Lagos, Manzini, Melbourne, Mexico City, Nairobi, New York, Singapore and Tokyo

\section{For Susan Arnold}

ISBN 978-0-333-32545-2

ISBN 978-1-349-17659-5 (eBook)

DOI 10.1007/978-1-349-17659-5 


\section{Contents}

Preface and Acknowledgements

List of Abbreviations

1 Host-Parasite Relationships ........................................... 1

2 Parasitic Organisms .......................................................5

3 Parasites of Man ............................................................... 24

$4 \quad$ Man as Host ............................................................. 51

5 The Environment of Human Parasitic Disease ........................ 65

6 Transmission and Infection .......................................... 76

$7 \quad$ Immune Responses ................................................... 87

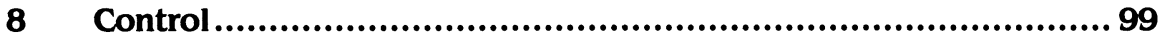

Suggestions for Further Reading and Reference ..................... 106

Index................................................................... 109 


\section{Preface \& Acknowledgements}

Until relatively recently, parasitology when applied to animal hosts was seen mainly as a rather specialized branch of zoology. Today it encompasses biochemistry, genetics, immunology, molecular biology, nutritional science, pharmacology and population biology. When man is the host, parasitology's interdisciplinary character becomes even more diverse as anthropology, economics, medical science, politics and sociology make their contributions. Parasitology is of much importance for those who live in the developing countries of the world and my concern for practical aspects was first aroused by my colleagues at Cornell University, New York. Professor Michael Latham and Dr. Lani Stephenson took me to work with them in Africa and Dr. Eduvigis Carrera and Dr. Patricia Day Bidinger shared with me their studies in Panama and India. I very much hope that Parasites and People will interest and help those who are beginning to work for the relief of human suffering.

The production of this book owes much to the efforts of Dr. P.L. Clarke, Science Editor of The Macmillan Press Ltd., and to Ms Paula Disanto Bensadoun, Mrs. Zina Bulstrode and Miss Linda Keymer. The entire manuscript 
was read and improved by Dr. Jean Martin, The Molteno Institute, University of Cambridge. Dr. Anne Keymer, also of The Molteno Institute, and Dr. G.E. Dappen, Department of Biology, Nebraska Wesleyan University, commented on several chapters. Mr. J. D. Crompton, University College, Oxford, helped me with various editorial chores. I thank them all and I accept full responsibility for the errors and mistakes that may remain.

The book could not have been written without the contributions of many scientists whose ideas, results and experiences are made freely available through libraries and learned journals. The text would have been unreadable if I had cited so many authors, but I am fully aware of my debt to them. I am also pleased to thank the copyright holders who kindly gave me permission to reproduce and use the following materials: Academic Press for Figure 2.1 redrawn from fig. 1.3 in Medical Virology (1970) by F. Fenner and D.0. White; American Institute of Biological Sciences for Tables $5.1,5.2$ and 5.3 which are based on tables 1 and 2 and information on page 679 in an article from Bioscience 32 ( 1982 ) by D.W.T. Crompton and M.C. Nesheim;

Blackwell Scientific Publications Ltd. for Table 7.3 based on table 2.1 in Essential Immunology (1971) by I.M. Roitt, and for Figure 2.3 redrawn from fig. 2.3 in Animal Microbiology 1 (1977) by A. Buxton and G. Fraser; Food and Agriculture Organization of the United Nations for Table 4.1 based on information on page 54 in Human Nutrition in Tropical Africa, 2nd edition (1979) by M.C. Latham; Harper and Row Publishers Inc. for Figure 2.2 redrawn from fig. 2.2 on page 19 in Microbiology (1980) edited by B.D. Davis, R. Dulbecco, H.N. Eisen and H.S. Ginsberg; Longman Group Ltd. for Table 4.2 
abstracted from table 13.1 in Human Nutrition and Dietetics, 6th edition (1982) by S. Davidson, R. Passmore, J.F. Brock and A.S. Truswell, and for Table 4.3 abstracted from table 1.1 in Practical Haematology, 4 th edition (1974) by J.V. Dacie and S.M. Lewis; Dr. Arno Peters of Bremen for Figure 5.1 which is based on his projection of the world; World Health Organization for Figure 4.1 redrawn with modifications from the flow diagram on page 8 in W.H.O. Technical Report Series No. 485 ( 1972 ), and for Figure 4.2 redrawn with modifications from fig. 1 (after Mata et al) in the chapter by J.E. Gordon in Nutrition in Preventive Medicine (1976) edited by G.H. Beaton and J.M. Bengoa.

Figures $2.5,6.2$ and 7.1 are redrawn from figs. $1.29,1.54,3.2,3.6,3.11,3.12,3.13,3.14,3.25$, 3.27 and 9.9 in Parasitic Worms (1980) by myself and S.M. Joyner, which was published in the Wykeham series of Taylor and Francis Ltd., London. Finally, I wish to acknowledge that $I$ have not traced the appropriate source of permission for Figure 5.3 which is based on graphs in a mimeographed article entitled 'International nutritional considerations: the point of view from the under developed world' by F.B. Monckeberg.

D.W.T. Crompton

Cambridge 


\section{Abbreviations}

$\begin{array}{ll}{ }^{\circ} \mathrm{C} & \text { degrees Celsius } \\ \text { DNA } & \text { deoxyribonucleic acid } \\ \text { e.g. } & \text { for example } \\ \text { GNP } & \text { gross national product } \\ \mathrm{H}_{2} \mathrm{O} & \text { water } \\ \text { MJ } & \text { megaJoule } \\ \text { MW } & \text { molecular weight } \\ \mathrm{N} & \text { north } \\ \% & \text { percentage } \\ \text { r.b.c. } & \text { red blood cell } \\ \text { RE } & \text { reticulo-endothelial (system) } \\ \text { RNA } & \text { ribonucleic acid } \\ \text { S } & \text { south } \\ \text { spp. } & \text { species (plural) } \\ \text { U.K. } & \text { United Kingdom } \\ \text { U.S.A. } & \text { United States of America } \\ \text { U.S. } \$ & \text { United States dollar } \\ \text { h } & \text { hour } \\ \text { min } & \text { minute } \\ \text { sec } & \text { second } \\ \text { yr } & \text { year } \\ & \end{array}$




$\begin{array}{ll}l & \text { litre } \\ \mathrm{dl} & \text { decilitre } \\ \mathrm{ml} & \text { millilitre } \\ \mathrm{kg} & \text { kilogram } \\ \mathrm{g} & \text { gram } \\ \mathrm{mg} & \text { milligram } \\ \mathrm{m} & \\ \mathrm{mm} & \text { metre } \\ \mu \mathrm{m} & \text { millimetre } \\ \mathrm{nm} & \text { nanometre }\end{array}$

Other abbreviations are explained in the text and tables. 